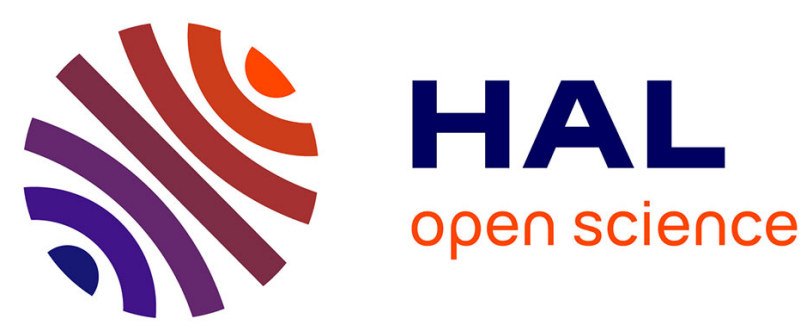

\title{
Rubella vaccine-induced granulomas are a novel phenotype with incomplete penetrance of genetic defects in cytotoxicity
}

\author{
Miriam Gross, Carsten Speckmann, Annette May, Tania Gajardo-Carrasco, \\ Katharina Wustrau, Sarah Lena Maier, Marcus Panning, Daniela Huzly, \\ Abbas Agaimy, Yenan Bryceson, et al.
}

\section{To cite this version:}

Miriam Gross, Carsten Speckmann, Annette May, Tania Gajardo-Carrasco, Katharina Wustrau, et al.. Rubella vaccine-induced granulomas are a novel phenotype with incomplete penetrance of genetic defects in cytotoxicity. Journal of Allergy and Clinical Immunology, In press, 10.1016/j.jaci.2021.05.007 . hal-03432275

\section{HAL Id: hal-03432275 \\ https://hal.science/hal-03432275}

Submitted on 17 Nov 2021

HAL is a multi-disciplinary open access archive for the deposit and dissemination of scientific research documents, whether they are published or not. The documents may come from teaching and research institutions in France or abroad, or from public or private research centers.
L'archive ouverte pluridisciplinaire HAL, est destinée au dépôt et à la diffusion de documents scientifiques de niveau recherche, publiés ou non, émanant des établissements d'enseignement et de recherche français ou étrangers, des laboratoires publics ou privés. 
1 Rubella vaccine-induced granulomas are a novel phenotype with incomplete penetrance of genetic defects in cytotoxicity

Miriam Groß, MSc ${ }^{1,2}$, Carsten Speckmann, MD ${ }^{1,3}$, Annette May, MD4, Tania Gajardo-

Carrasco, $\mathrm{MSc}^{5,6}$, Katharina Wustrau, MD${ }^{7}$, Sarah Lena Maier, $\mathrm{MD}^{7}$, Marcus Panning, $\mathrm{MD}^{8}$, Daniela Huzly, $\mathrm{MD}^{8}$, Abbas Agaimy, $\mathrm{MD}^{9}$, Yenan T. Bryceson, $\mathrm{PhD}^{10,11}$, Sharon Choo, MD ${ }^{12}$, CW Chow, MD ${ }^{13}$, Gregor Dückers, MD ${ }^{14}$, Anders Fasth, MD, $\mathrm{PhD}^{15}$, Sylvie Fraitag, $\mathrm{MD}^{16}$, Katja Gräwe, MTA${ }^{1}$, Sabine Haxelmans, TA ${ }^{17}$, Dirk Holzinger, $M D^{18}$, Ole Hudowenz, $M D^{19}$, Judith Hübschen, $\mathrm{PhD}^{20}$, Claudia Khurana, $\mathrm{MD}^{21}$, Korbinian Kienle, $\mathrm{PhD}^{22}$, Roman Klifa, $\mathrm{MD}^{23}$, Klaus Korn, $\mathrm{MD}^{24}$, Heinz Kutzner MD ${ }^{25}$, Tim Lämmermann, $\mathrm{PhD}^{22}$, Svea Ledig, $\mathrm{MD}^{7}$, Dan Lipsker, $\mathrm{MD}^{26}$, Marie Meeths, MD, $\mathrm{PhD}^{27,28,29}$, Nora Naumann-Bartsch, $\mathrm{MD}^{30}$, Jelena Rascon, $\mathrm{MD}, \mathrm{PhD}^{31,32}$, Anne Schänzer, $\mathrm{MD}^{33}$, Maximilian Seidl, $\mathrm{MD}^{4,34}$, Bianca Tesi, MD, $\mathrm{PhD}^{28,35}$, Christelle Vauloup-Fellous, $\mathrm{MD}^{36}$, Beate Vollmer-Kary, $\mathrm{TA}^{4}$, Klaus Warnatz, MD ${ }^{37,38}$, Claudia Wehr, $\mathrm{MD}^{39,38}$, Bénédicte Neven, MD, $\mathrm{PhD}^{40,41}$, Pablo Vargas, $\mathrm{PhD}^{42}$, Fernando $\mathrm{E}$. Sepulveda, $\mathrm{PhD}^{5,6,43}$, Kai Lehmberg, MD , Annette Schmitt-Gräff, MD ${ }^{44}$, Stephan Ehl, $\mathrm{MD}^{1}$

1 Institute for Immunodeficiency, Center for Chronic Immunodeficiency, Faculty of Medicine, University Medical Center Freiburg, Freiburg, Germany

2 Faculty of Biology, University of Freiburg, Freiburg, Germany

3 Center for Pediatrics and Adolescent Medicine, Medical Center, Faculty of Medicine, University of Freiburg, Freiburg, Germany

4 Institute for Surgical Pathology, Medical Center - University of Freiburg, Freiburg, Germany 
5 Molecular basis of altered immune homeostasis laboratory, INSERM UMR1163,

Paris, France

6 Université de Paris, Imagine Institute, F-75015, Paris France

7 Division of Pediatric Stem Cell Transplantation and Immunology, University Medical

Center Hamburg Eppendorf, Germany

8 Institute of Virology, Freiburg University Medical Center, Faculty of Medicine, University of Freiburg, Freiburg, Germany

9 Institute of Pathology, Friedrich Alexander University Erlangen-Nürnberg, University Hospital, Erlangen, Germany

10 Department of Medicine, Center for Hematology and Regenerative Medicine, Karolinska Institutet, Stockholm, Sweden

11 Broegelmann Research Laboratory, Department of Clinical Sciences, University of Bergen, Bergen, Norway

12 Department of Allergy and Immunology, The Royal Children's Hospital, Melbourne, VIC, Australia

13 Department of Anatomical Pathology, Royal Children's Hospital, Melbourne, Australia

14 Helios Klinikum Krefeld, Zentrum für Kinder- und Jugendmedizin 15 Dept of Pediatrics, Institute of Clinical Sciences, Sahlgrenska Academy University of Gothenburg, Sweden

16 Department of Pathology, Necker-Enfants Malades Hospital, Paris, France 17 Life Imaging Center (LIC), University of Freiburg, Germany 18 Department of Pediatric Hematology-Oncology, University of Duisburg-Essen, Essen, Germany 19 Department of Rheumatology, Immunology, Osteology and Physical Medicine, Campus Kerckhoff of Justus-Liebig-University Giessen, Bad Nauheim, Germany 
20 World Health Organization European Regional Reference Laboratory for Measles and Rubella, Luxembourg Institute of Health, Department of Infection and Immunity, Esch-sur-Alzette, Luxembourg

21 Department of Pediatric Hematology and Oncology, Children's Center Bethel, University Hospital OWL / University Bielefeld, Germany

22 Max Planck Institute of Immunobiology and Epigenetics, Freiburg, Germany

23 Immunology and Pediatric Hematology Department, Assistance PubliqueHôpitaux de Paris, Paris, France

24 Institute of Virology, University Hospital Erlangen, Friedrich-Alexander-University

Erlangen-Nürnberg (FAU), Erlangen, Germany

25 Dermatopathology, Friedrichshafen, Germany

26 Faculté de Médecine, Université de Strasbourg and Clinique Dermatologique, Hôpitaux Universitaires, Strasbourg

27 Childhood Cancer Research Unit, Department of Women's and Children's Health, Karolinska Institutet, Stockholm, Sweden.

28 Department of Molecular Medicine and Surgery, Center for Molecular Medicine, Karolinska Institutet, Stockholm, Sweden 29 Theme of Children's Health, Karolinska University Hospital, Stockholm, Sweden. 30 Division of Pediatric Hematology and Oncology, Department of Pediatrics, University Hospital Erlangen, Erlangen, Germany

31 Center for Pediatric Oncology and Hematology, Vilnius University Hospital Santaros Klinikos, Vilnius, Lithuania

32 Faculty of Medicine, Vilnius University, Vilnius, Lithuania

33 Institute of Neuropathology, Justus Liebig University Giessen, Giessen, Germany 34 Institute of Pathology, Heinrich Heine University and University Hospital of Duesseldorf, Duesseldorf, Germany 
7735 Department of Clinical Genetics, Karolinska University Laboratory, Karolinska University Hospital, Stockholm, Sweden.

36 AP-HP, Hôpital Paul-Brousse, Department of Virology, WHO Rubella National

Grossesse (GRIG), University Paris Saclay, INSERM U1193, 94804 Villejuif, France

37 Department of Rheumatology and Clinical Immunology, Faculty of Medicine, University Medical Center Freiburg, Freiburg, Germany

38 Center for Chronic Immunodeficiency, Faculty of Medicine, University Medical Center Freiburg, Freiburg, Germany

39 Department of Medicine I, Medical Center - University of Freiburg, Faculty of Medicine, University of Freiburg, Germany

40 Pediatric Hematology-Immunology and Rheumatology Department, Hôpital Necker-Enfants Malades, AP-HP Centre Université de Paris, Paris, France 41 Université de Paris, Imagine Institute, Laboratory of Immunogenetics of Pediatric Autoimmunity, INSERM UMR 1163, Paris, France

42 Institut Curie, PSL Research University, CNRS UMR 144 and Institut Pierre-Gilles de Gennes, PSL Research University, Paris, France; INSERM U932 Immunité et Cancer, Institut Curie, PSL Research University, Paris, France

43 Centre national de la recherche scientifique - CNRS 44 University of Freiburg, Freiburg, Germany 
99

100

101

102

103

104

105

106

107

108

109

110

111 TGC was supported by the French State funding from the Agence Nationale de la

112 Recherche under "Investissements d'avenir" program (ANR-10-IAHU-01) and the

113 "Fondation Bettencourt Schueller".

\section{Disclosure of potential conflict of interest}

116 SE received a research grant from UCB outside the submitted work. AF received

117 personal fees outside the submitted work from Lipum as member of the advisory board.

118 All other authors have nothing to disclose. 
Abstract (246 words)

Background: Rubella virus-induced granulomas have been described in patients with various inborn errors of immunity. Most defects impair T-cell immunity, suggesting a critical role of T cells in rubella elimination. However, the molecular mechanism of virus control remains elusive.

Objective: To understand the defective effector mechanism allowing rubella vaccine virus persistence in granulomas.

Methods: Starting from an index case with Griscelli syndrome type 2 and rubella skin granulomas, we combined an international survey with a literature search to identify patients with cytotoxicity defects and granuloma. We performed rubella virus immunohistochemistry and PCR and T-cell migration assays.

Results: We identified 21 patients with various genetically confirmed cytotoxicity defects, who presented with skin and visceral granulomas. Rubella virus was demonstrated in all 12 accessible biopsies. Granuloma onset was typically before age 2 years and lesions persisted from months to years. Granulomas were particularly frequent in MUNC13-4 and RAB27A deficiency, where $50 \%$ of patients at risk were affected. Although these proteins have also been implicated in lymphocyte migration, 3D migration assays revealed no evidence of impaired migration of patient $\mathrm{T}$ cells. Notably, patients showed no evidence of reduced control of concomitantly given measles, mumps or varicella live-attenuated vaccine or severe infections with other viruses.

Conclusions: We identify lymphocyte cytotoxicity as a key effector mechanism for control of rubella vaccine virus, without evidence for its need in control of live measles, mumps or varicella vaccines. Rubella vaccine-induced granulomas are a novel phenotype with incomplete penetrance of genetic disorders of cytotoxicity. 
145 Clinical Implications (28 words):

146 Lymphocyte cytotoxicity is important for control of rubella vaccine virus persistence.

147 Patients with genetic defects of cytotoxicity including albinism syndromes should not 148 be vaccinated with rubella live vaccine.

150 Capsule Summary (35 words).

151 Lymphocyte cytotoxicity is important for control of rubella vaccine without evidence for 152 its need to control concomitantly given live vaccines. Rubella vaccine-induced 153 granulomas are a novel phenotype with incomplete penetrance of disorders of 154 cytotoxicity.

156 Key words (up to 10):

157 Cytotoxicity, rubella virus, live vaccine, granuloma, primary immunodeficiency, 158 hemophagocytic lymphohistiocytosis, Griscelli syndrome type 2

\section{Abbreviations.}

161 AT - Ataxia telangiectasia

162 CHS - Chédiak-Higashi syndrome

163 CMV - Cytomegalovirus

164 CNS - central nervous system

165 CTL - cytotoxic T lymphocyte

166 DTH - delayed type hypersensitivity

167 EBV - Epstein-Barr virus

$168 \mathrm{fHLH}-$ familial hemophagocytic lymphohistiocytosis 
$169 \mathrm{HLH}$ - hemophagocytic lymphohistiocytosis

170 HSCT- hematopoietic stem cell transplantation

171 IEI - inborn errors of immunity

172 GS2 - Griscelli syndrome type 2

173 LCMV - lymphocytic choriomeningitis virus

$174 \operatorname{MMR}(\mathrm{V})$ - measles, mumps, rubella, (varicella) live-attenuated vaccine

175 PBMCs - Peripheral blood mononuclear cells

176 PCR - polymerase chain reaction

177 PID - primary immunodeficiency

$178 \mathrm{RV}$ - rubella virus

179 RV-C - rubella virus capsid

180 VZV- varicella-zoster virus 
181

182

183

184

185

\section{Introduction}

Perforin-mediated target cell lysis is a key effector mechanism of CD8+ T cells and NK cells. A key function ascribed to cytotoxicity is the control of viral infections by elimination of virus-infected cells (1). This was first documented in perforin-deficient mice that fail to control infection with lymphocytic choriomeningitis virus (LCMV) (2). Patients with genetically impaired perforin-mediated cytotoxicity (including patients with familial hemophagocytic lymphohistiocytosis FHL2-5, Griscelli syndrome type 2, GS2, and Chédiak-Higashi syndrome, CHS) are predisposed to develop the hyperinflammatory syndrome of familial hemophagocytic lymphohistiocytosis (fHLH) (3). Disease onset can be associated with viral infections (4) and in particular uncontrolled infection with Epstein-Barr virus (EBV) is observed in some fHLH patients. However, in the context of acute fHLH it is difficult to separate whether disease severity reflects lack of antiviral function or rather impaired control of immune stimulation by failure to eliminate antigen-presenting cells (5). Notably, in the majority of infants with the most severe forms of the disease, no viral trigger can be identified (6). There are no reports on live vaccine persistence in fHLH patients. Moreover, uncontrolled viral infection is not a general phenotype of fHLH patients, even when they are not transplanted in the first 2-3 years of life (7). Thus, from a biological point of view, the role of cytotoxicity in the control of many human viruses is not so evident.

Granulomas are organized structures formed by macrophages and other immune cells that participate in antimicrobial defense by preventing spread of a persistent pathogen (8). This also includes viral infections such as measles and EBV (9). Recently, elegant work has demonstrated persistence of rubella virus (RV) vaccine strain RA27/3 in skin and visceral granulomas of patients with inborn errors of immunity (IEI) over decades (10-12). Most commonly, these RV associated granulomas were detected in patients with Ataxia-telangiectasia (AT) and other DNA repair disorders, followed by patients 
207 with various combined immunodeficiencies (13). The T-cell lymphopenia in most of 208 these patients in combination with evidence of cytotoxic T lymphocyte (CTL) epitope 209 escape mutations in the viral genome (14) suggests a key role for CTL in limiting the 210 observed RV persistence in M2 macrophages (12). Since CD8 T cells predominate 211 around the granulomas, it has been suggested that beyond an initial numeric T-cell 212 deficiency allowing prolonged RV replication, functional impairments such as T-cell exhaustion contribute to RV persistence (13). However, the molecular mechanisms

214 that are essential for rubella vaccine virus control remain incompletely understood.

215 Here we describe a cohort of patients with hereditary cytotoxicity defects, who 216 presented with rubella virus-containing skin and visceral granulomas. There was no 217 evidence that these patients lacked control of concomitantly given measles, mumps or 218 varicella virus or had generally increased susceptibility to viral infections apart from 219 EBV in the context of HLH. Clinically, these observations identify rubella-induced 220 granulomas as a novel phenotype with incomplete penetrance of patients with genetic 221 defects of cytotoxicity. From a biological point of view, they support the concept that 222 lymphocyte cytotoxicity is not needed as effector mechanism against viruses in 223 general, but rather has a selective role against some specific viruses. 


\section{Materials and Methods}

225 Patient Recruitment

226 Patients with cutaneous granulomas and cytotoxicity defects ("granuloma cohort") 227 were identified via literature search (PubMed search terms: haemophagocytic lymphohistiocytosis / HLH / disease name / gene name AND granuloma / skin / cutaneous) and the databases from the German HLH Reference Centers Freiburg and Hamburg. Additional cases were identified through our international network of colleagues from the European Society for Immunodeficiencies (ESID), the Inborn Errors Working Party and the Histiocyte Society. Patients were included based on the following criteria: (i) diagnosis of FHL, CHS or GS2 (clinical in 1 GS2 patient, genetic all other patients) (ii) description of skin lesions consistent with granulomas in the patient files (described as: papular, pustular, maculopapular, granulomatous), and available in all but 1 patient (iii) photographs of the skin lesions, histology, rubella immunohistochemistry or PCR consistent with the diagnosis.

An additional, partly overlapping "at risk cohort" comprises patients documented in the German HLH Study between 01/1997 and 06/2020 with genetically confirmed cytotoxicity defects. This study captures more than $80 \%$ of such patients manifesting

241 in Germany. We included all patients with a minimum age of 18 months before onset 242 of HLH and/or HSCT to restrict the analysis to patients with likely vaccine exposure. 243 Patients who were known not to be vaccinated against rubella or had a negative 244 serology for MMR were excluded. For patients with unknown vaccination status, 245 vaccination against rubella was presumed based on the high MMR vaccination rate in 246 Germany (15).

247 The research protocol was approved by the Ethics committee, University of Freiburg 248 (EK No. 159/19). All patients in the German HLH study gave informed consent. 
249

250

251

252

253

\section{Immunohistochemistry}

For detection of the rubella virus in patient biopsies, tissue sections were cut from formalin-fixed, paraffin-embedded tissue samples and used for subsequent immunohistochemical analysis. The presence of the viral capsid was visualized by chromogenic or fluorescent detection using the mouse monoclonal anti-rubella virus capsid antibody (clone 9B11, 1:500, Abcam). Tissue sections from sarcoidosis patients were used as negative controls. Staining results were interpreted by an experienced pathologist, based on staining intensity, tissue location of the RV-positive signal and the infected cell type. Further details are provided in the supplementary material.

\section{Molecular Analysis}

Frozen skin samples were used to extract RNA for subsequent real-time RT-PCR for rubella virus according to standards of practice.

\section{Cell Culture}

Peripheral blood mononuclear cells (PBMCs) from patients and healthy controls were isolated from whole blood using ficoll density gradient centrifugation. To generate CD8+ T-cell lines, PBMCs were stimulated with PHA (1.25 $\mu \mathrm{g} / \mathrm{ml}$, Remel), IL-2 (1:100, cell culture supernatant from an IL-2 producing cell line) and gamma-irradiated feeder cells (61.8 Gy, pool of allogeneic PBMCs). Cells were sorted for CD8+ T cells after the first round of stimulation. Further details are provided in the supplementary material.

\section{Flow Cytometry Based Assays}

NK cell and CTL degranulation assays were performed as previously described (16). CXCR3 expression in resting or CXCL11 (100 nM, PeproTech) stimulated CD8+ T-cell lines was analyzed by flow cytometry using an anti-CXCR3 antibody (clone \# 49801, R\&D Systems). Details of the protocol are provided in the supplementary material. 


\section{T-cell Migration Assays}

274 The chemotactic response of CD8+ T-lines to CXCL10 (PeproTech) or CXCL12 275 (PeproTech) was analyzed using Transwell囚 permeable supports for 24 well plates 276 (polycarbonate membrane, $5 \mu \mathrm{m}$ pores, Corning). Migration in micro-channels was 277 performed as described in previously (17). To assess T-cell migration in complex 3D 278 environment, collagen experiments were performed as previously described (18). 279 Details of the T-cell migration protocols are provided in the supplementary material. 


\section{Results}

282

\section{A patient with Griscelli syndrome type 2 and rubella granulomas}

A 2-year-old girl from a consanguineous family was referred due to persistence of a generalized, papulo-pustular rash over 6 months. Upon admission, the non-itching, papular lesions were found on arms, legs and face (Figure S1A). The patient had silverblond hair (Figure S1A), but her medical history did not reveal relevant infections or hospitalizations. Based on characteristic pigment distribution in the hair shaft (Figure S1B) and a defect in NK and T-cell degranulation (Figure S1C), she was given the clinical diagnosis of GS2, which was confirmed by identification of a homozygous splice site mutation in $R A B 27 A$ (c.240-2A $>\mathrm{T}$ ). A skin biopsy showed necrotizing epithelioid and giant cell granulomas in the dermis (Figure S1D). Cultures were negative for bacteria and fungi and histochemical stainings did not reveal fungal mycelia or acid-fast bacteria. PCR was performed for mycobacteria and viruses including cytomegalovirus, varicella zoster, mumps, measles and, based on recent reports, rubella virus (RV) $(10,12)$. Indeed, only the PCR for RV was positive and subsequent immunohistological stainings showed RV-positive cells in the center of the granulomas (Figure S1D). The extended patient history revealed measles, mumps and rubella (MMR) vaccinations at 15 and 25 months of age. Rubella was not detected in respiratory secretions or blood and the patient had a protective IgG titer against rubella.

\section{Skin and visceral granulomas are common in patients with genetic defects in}

\section{cytotoxicity}

While rubella-associated granulomas have been described mostly in IEI patients with defective T-cell immunity, they have so far not been reported in patients with GS2. To address whether RAB27A deficiency and potentially other genetic defects in cytotoxicity predispose to rubella granulomas, we combined a literature search with an 
analysis of the databases of the German HLH reference centers and enquiries through an international network of colleagues. Twenty additional patients with a history of skin or visceral granuloma were identified based on a clinical description given by referring physicians, the medical reports or publications (Table 1). We evaluated three additional criteria to verify the diagnosis in these 20 patients: (i) photo documentation compatible with skin granulomas, (ii) histological confirmation of granulomas and (iii) identification of rubella by immunohistochemistry and/or PCR. We had access to formalin-fixed paraffin embedded skin biopsies from 10 patients (P2,3,6,8,9,12,15,17,18,19) and detected the RV antigen by immunohistochemistry in all samples. Additionally, rubella was identified in 3 of these patients $(P 1,6,15)$ by RT-PCR analysis of fresh skin biopsies. Sequence analysis of the PCR products in 2 patients $(P 6,15)$ revealed a sequence identical (P6, $131 \mathrm{nt}$ sequenced) or nearly identical (P15, $739 \mathrm{nt}$ sequenced, $98.2 \%$ alignment) with that of the rubella RA27/3 vaccine strain. Overall, $7 / 21$ patients fulfilled 2 criteria, 3/21 fulfilled 3 criteria and 10/21 fulfilled all 4 criteria (Table 1). In addition to skin granulomas, some patients had rubella-positive extracutaneous granulomas in the liver $(\mathrm{P} 12)$ or lung $(\mathrm{P} 8,19)$, detected in the context of liver or interstitial lung disease. P14 only presented with lung granulomas (Table 1). Among the 21 patients in this "granuloma cohort", 13 had RAB27A deficiency, 5 had MUNC134 deficiency, 2 had PRF1 deficiency and 1 had MUNC18-2 deficiency (Table 1). Patients with FHL2 (perforin deficiency), FHL3 (MUNC13-4 deficiency) or FHL5 (MUNC18-2 deficiency) had at least one point or splice site mutation (Suppl. Table 1) possibly indicating hypomorphic disease variants.

\section{Clinical and immunohistochemical variability of granulomas}

Most patients presented with isolated, non-confluent maculopapular or pustular lesions on arms, legs and face, which in some cases developed into hyperkeratotic papules (P6, P15). However, papules were also found on the trunk or buttocks (P3, P7, P8, 
$332 \mathrm{P} 10, \mathrm{P} 11, \mathrm{P} 13, \mathrm{P} 21)$ (Figure 1), 2 patients only had a single granulomatous lesion on 333 the leg (P17, P19) which gradually increased in size. Overall, clinical manifestations 334 were similar in patients with different cytotoxicity defects (Figure 1, particularly P7, P18 and P3, P15). Positive RV immunostaining was found in granulomas in the dermis and granuloma-like histiocytic aggregates in the dermis, lung and liver (Figure 2). The quantity of RV positive cells varied considerably between patients. Whereas in some sections the RV antigen could be detected in many epithelioid cells in the center of granulomas, others only showed a few positive cells. RV-positive cells also stained positive for the macrophage marker CD68 (Figure 2), demonstrating that macrophages were the cell type harboring the virus. Granulomas in the dermis were usually

342 epithelioid and occasionally contained multinucleated giant cells (Figure 2A). Some granulomas also showed central necrosis. Lymphocytic infiltrates (including CD8+ T cells) were located in the periphery of the granulomas (Figure 2A). Hyper(para)keratosis of the epidermis was seen in $5 / 11$ skin samples.

\section{Clinical course of granulomas and response to treatment}

The temporal relationship between vaccination, onset and persistence of granulomas is summarized in Table 1 and Figure 3. Patients had received their first MMR dose between 12-52 months of age (median 13.5 M, n=14) and developed granulomas 4 months (median, range $0.5 \mathrm{M}-3 \mathrm{Y}, \mathrm{n}=14$ ) later. The median age at granuloma onset was 20 months $(n=18)$ and preceded HLH development in all 16 patients who eventually developed HLH. Only 4 patients showed HLH symptoms within 3 months after granuloma onset. In P8, Pseudomonas aeruginosa superinfection of the skin lesions was a possible trigger of incomplete HLH and in P4 HLH onset was linked to 355 EBV infection. No possible infectious triggers were given for P20 and P21, raising the possibility that the rubella vaccination could have triggered the HLH episode. Apart 
CMV-associated hepatitis in P18, none of the patients were reported to have suffered from severe or unusual courses of viral infections.

Skin granulomas persisted over months or even years (range $1.5 \mathrm{M}-6.5 \mathrm{Y}, \mathrm{n}=18$ ), but eventually spontaneously resolved with variable residual scars in 7/21 patients. P17 had a single lesion increasing in size over the course of 6.5 years which was excised in total and did not reoccur. Systemic glucocorticoids were associated with improvement of skin lesions in 5/6 patients. In 4 patients (P3, P4, P20, P21), HLHdirected therapy (mostly HLH94) was not associated with deterioration of the granulomas but induced partial or complete remission in P3 and P4. Five patients entered HSCT with skin lesions, which completely resolved in 4 within a few weeks. P3 had resolution of the erythematous component, but atrophic papules persisted and were later surgically excised.

\section{Risk of rubella granuloma varies with genetic diagnosis}

To understand how frequently patients with cytotoxicity defects are affected by skin granulomas, we identified 61 patients with genetically confirmed cytotoxicity defects and a minimum age of 18 months before clinical onset of HLH via the databases of the German national HLH study (Figure 4A). In this "at risk cohort" (including 9 patients that were also part of the "granuloma cohort"), rubella vaccination or antibody titers against rubella had been explicitly documented in 43 patients. In the remaining 18 patients, rubella vaccination was presumed based on $97 \%$ MMR vaccination rates in Germany (15). Patient reports revealed skin lesions consistent with rubella granulomas in 9/61 patients (14.7\%) (Figure 4B) and RV could be demonstrated in all 5 accessible biopsies. Skin lesions were described in 1/11 FHL3, 1/14 FHL5 and 7/14 GS2 patients (Figure 4B), but not in patients with CHS, FHL2 or FHL4. 


\section{No evidence for impaired T-cell migration in patients with genetic defects of}

\section{lymphocyte cytotoxicity}

Literature indicates a role for RAB27A in cell motility (19-22) and GS2 patients were shown to have absent delayed-type cutaneous hypersensitivity (DTH) responses $(23,24)$. Since nearly all patients had deficiency in RAB27A or the RAB27A interaction partner MUNC13-4, we considered that the mutations impair T-cell migration and therefore rubella clearance in the skin.

Since the chemokine receptor CXCR3 and its ligands are important for directed migration of T cells and NK cells into inflamed tissues and contribute to virus control in the skin (25-27), we first tested expression and regulation of CXCR3 (Figure 5A). Surface expression of CXCR3 on CD8+ T cells was similar in patient and control cells and stimulation with CXCL11 caused a comparable downregulation and re-expression kinetics of CXCR3. Moreover, patient cells showed concentration-dependent migration towards the chemokine CXCL10 that was comparable with control cells (Figure 5B). To investigate the motility of RAB27A- and MUNC13-4-deficient CD8+ T cells in a more confined environment, we examined the migration of fluorescently labelled T-cell blasts along $4 \mu \mathrm{m}$ wide micro-channels (Figure 5C). Patient T cells moved at the same speed as control cells. Also, when the skin's dermal layer was mimicked by using a threedimensional (3D) collagen gel matrix, time-lapse video microscopy revealed no differences in speed between CD8+ T cells from patients and healthy controls (Figure 5D). In summary, we could not provide evidence that RAB27A- and MUNC13-4deficiency affects the spontaneous or chemokine-induced motility of CD8+ T cells. 


\section{Discussion}

406 Here we show that rubella vaccine-induced granulomas are a novel phenotype with incomplete penetrance in patients with defects of cytotoxicity. This is illustrated by long-term persistence of attenuated rubella vaccine strain in skin and organ granulomas in some, but not all rubella-vaccinated patients with various genetic defects of cytotoxicity.

411 Rubella-associated granulomas are a known complication in IEls (10-12,28-32). In a 412 series of 66 patients, 17 suffered from AT, 16 from atypical SCID, 25 from various forms of combined immunodeficiencies, 6 patients from CVID and 2 patients from X-

414 linked agammaglobulinemia (13). Apart from the latter two patients, the common theme in all of these diseases are defects in T-cell immunity, in most cases associated with T-cell lymphopenia. We describe here for the first time such lesions in a cohort of

417 patients with normal T-cell numbers, but various defects in lymphocyte cytotoxicity. These observations strongly suggest that cytotoxicity is a key effector mechanism in T cell mediated control of rubella virus. This raises the question, whether impaired cytotoxicity may also contribute to granuloma development in other IEI such as AT.

421 However, there is no evidence that lymphocyte cytotoxicity is impaired in AT patients 422 (33). Moreover, in most AT patients presenting with rubella granulomas, T-cell 423 lymphopenia was documented, suggesting that similar to atypical SCID/CID patients, 424 the numeric T-cell deficiency is a key factor in these diseases.

425 The clinical characteristics of the granulomas in our cohort showed many similarities 426 with those of the published IEI patients. We also observed a time lag between MMR 427 vaccination and granuloma onset of several months to years. We found similar 428 immunohistological characteristics with positive rubella staining of variable extent and not correlating with granuloma severity, located in macrophages within granulomas. 
430 Overall, lesions in our patients were less severe than some of those described in

431

432

published IEI patients. Several patients had only a few non-ulcerated, disseminated nodules or superficial plaques, that spontaneously resolved with variable scar formation without treatment after several months in one third of the cases. However, in the majority of patients, granulomas persisted longer and we also found rubellaantigen in visceral organ granulomas (liver and lung) in 5/21 patients years after vaccination. Notably, the immunosuppressive treatment for $\mathrm{HLH}$ in some patients led to partial remission and, as observed previously (32), HSCT performed to treat the underlying genetic defect also cured the granulomas in $4 / 5$ patients. This suggests that the ongoing inflammatory response is an important factor of the tissue pathology and although this is likely to be driven by the virus, the risk of secondary viral dissemination is low.

One limitation of our study was that we were able to analyze skin and visceral biopsies for the presence of the rubella virus only in $12 / 21$ patients by immunohistochemistry. However, we could demonstrate viral protein in all of them. In 3 patients we had additional access to fresh biopsies, enabling the detection of RV by RT-PCR in all analyzed patients. For the remaining 9/21 patients, we did not have access to biopsies. However, in an effort to minimize misdiagnosis, we carefully considered their clinical morphology, the histopathological findings and the time of appearance relative to rubella vaccination.

Why have skin granulomas so far only rarely been reported in patients with cytotoxicity defects? To address the question, whether granuloma formation was a more common phenomenon, we analyzed an "at risk cohort" of 61 patients with genetically confirmed cytotoxicity defect and documented or likely exposure to the MMR vaccine. Based on this analysis, patients with cytotoxicity defects had at least a 1:7 risk to develop skin 
455 granulomas after MMR vaccination. Patients with GS2 had the highest risk with 1:2 patients eventually developing granulomas during childhood. This indicates that, as in AT, granuloma development in patients with cytotoxicity defects is a phenotype with partial penetrance. Notably, NK cell degranulation was similar in GS2 patients with or without granulomas, suggesting that so far unknown factors in addition to the impaired cytotoxicity determine whether MMR vaccination results in granuloma formation. These could also include factors associated with the vaccine preparation or site of injection.

To further explore why GS2 patients were overrepresented in our cohort, we considered the hypothesis that impaired rubella control in the skin could be attributed in part to a T-cell migration defect. This was based on the observation that patients with RAB27A deficiency lack delayed-type skin hypersensitivity reactions $(23,24)$. Moreover, human T cells with RAB27A deficiency were reported to display decreased chemotaxis towards CXCL12 $(19,21)$ and RAB27A-deficient murine neutrophils show diminished migration in vitro and in vivo (34). In contrast to these findings, we could not demonstrate decreased chemotaxis towards CXCL12 of RAB27A-deficient or MUNC13-4-deficient CD8+ T cells. One explanation for this discrepancy could be the differences in assay setup. Indeed, Franciszkiewic et al. observed diminished migration towards CXCL12 only after recent TCR activation, which they attributed to disturbed synaptic secretion of CCL5 in RAB27A-deficient cells, which is needed for regulated increase of CXCR4 surface expression (21). Since the collagen fiber network of the dermis imposes significant physical constraints on immune cells, we also tested the motility of patient $T$ cells in microchannels and a more complex $3 \mathrm{D}$ collagen gel environment. However, also in these assays we found no evidence of impaired T-cell migration in the absence of RAB27A or MUNC13-4. 
480

481

482

Importantly, rubella granulomas were not only detected in patients with defects at variable steps of the degranulation machinery but also in patients with perforin deficiency. The common mechanistic basis of these diseases is impairment of lymphocyte cytotoxicity. Given that most other IEl-related granulomas were observed in patients with T-cell deficiencies, it is therefore plausible to assume that $\mathrm{T}$ cell mediated cytotoxicity is a key effector mechanism to control rubella infection. Hence, the overrepresentation of patients with GS2, FHL3, FHL5 and some patients with hypomorphic FHL2 may be explained by the fact that the residual cytotoxicity in these patients is sufficient to reach the age of MMR vaccination without HLH manifestation, but insufficient to reliably control rubella virus. In contrast, as shown previously, patients with FHL4 and CHS have a milder impairment of cytotoxicity $(35,36)$ and may therefore be able to control the vaccine.

It is notable that all patients with rubella granulomas controlled the concomitantly applied attenuated mumps, measles and in several cases varicella live vaccines without obvious clinical sequelae, as shown also in other IEI associated with rubella granulomas $(10,12,14)$. This is unlikely due to different tissue tropism, since not only rubella virus, but also measles and varicella vaccine virus can be isolated from the skin of immunodeficient patients with vaccine-induced rashes $(37,38)$. Moreover, our patients did not suffer from generally increased susceptibility to severe or recurrent viral infections, although exposure to wild-type viruses is likely to require more active effector functions than challenge with an attenuated live vaccine. A notable exception was EBV, which was implicated as a trigger of $\mathrm{HLH}$ in 3/16 patients who eventually developed this disease.

Is lymphocyte cytotoxicity maybe not as broadly required for control of viral infections as generally assumed? Doubts about this concept also emerge from murine studies. 
505 Perforin-deficient (PKO) mice fail to control infection with lymphocytic choriomeningitis

506

507

508

509

510

511

512

513

514

515

516

517

518

519

520

521

522

523

524

525

526

527

528

529

virus (LCMV), murine cytomegalovirus (MCMV), Theiler's Murine Encephalomyelitis or ectromelia virus (39-43). However, apart from these prominent examples, cytotoxicity is redundant for the elimination of a large number of other murine host-specific viruses (pneumonia virus of mice, murine gammaherpesvirus 68, JHMV strain of mouse hepatitis virus) (44-46) and viruses not restricted to mice (Vesicular stomatitis virus, Semliki Forest virus, vaccinia virus, cowpox virus, influenza virus, respiratory syncytial virus, Rotavirus) $(39,43,47-49)$. Thus, our human data support the view that cytotoxicity is not needed as an effector mechanism against viruses in general, but rather has a selective role against a few specific viruses (50), including rubella virus.

In summary, we document that patients with cytotoxicity defect are at risk of developing rubella virus containing skin and visceral granulomas after MMR vaccination, but do not seem at risk for developing complications associated with uncontrolled measles, mumps or varicella infection. Skin granulomas can be the presenting manifestation of these genetic defects and they should be considered in the differential diagnosis in young children with persistent granulomas of unknown cause. Importantly, children with known cytotoxicity defects should not be given live MMR vaccines.

\section{Acknowledgments}

We are grateful to the FREEZE Biobank (A. Nieters) of the Medical Faculty, University of Freiburg and the $\mathrm{CCl}$ Advanced Diagnostic Unit (I. Fuchs), Medical Center, University of Freiburg for excellent services.

SE wishes to gratefully dedicate this manuscript to Rolf Zinkernagel, Hans Hengartner, Hanspeter Pircher and Peter Aichele from the former Institute for Experimental Immunology, Zürich. 


\section{References}

532 1. Harty JT, Tvinnereim AR, White DW. CD8+ T cell effector mechanisms in resistance to infection. Annu Rev Immunol. 2000;18(1):275-308.

2. Kägi D, Ledermann B, Bürki K, Seiler P, Odermatt B, Olsen KJ, et al. Cytotoxicity mediated by $T$ cells and natural killer cells is greatly impaired in perforin-deficient mice. Nature. 1994 May;369(6475):31-7.

3. Stepp SE. Perforin Gene Defects in Familial Hemophagocytic Lymphohistiocytosis. Science. 1999 Dec 3;286(5446):1957-9.

4. Brisse E, Wouters $\mathrm{CH}$, Andrei G, Matthys P. How Viruses Contribute to the Pathogenesis of Hemophagocytic Lymphohistiocytosis. Front Immunol [Internet]. 2017 Sep 7 [cited 2017 Nov 10];8. Available from: http://journal.frontiersin.org/article/10.3389/fimmu.2017.01102/full

5. Terrell CE, Jordan MB. Perforin deficiency impairs a critical immunoregulatory loop involving murine CD8+ T cells and dendritic cells. Blood. 2013 Jun 27;121(26):5184-91.

6. Heeg M, Ammann S, Klemann C, Panning M, Falcone V, Hengel H, et al. Is an infectious trigger always required for primary hemophagocytic lymphohistiocytosis? Lessons from in utero and neonatal disease. Pediatr Blood Cancer. 2018 Nov;65(11):e27344.

7. the HLH study of the GPOH, Ammann S, Lehmberg K, zur Stadt U, Klemann C, Bode SFN, et al. Effective Immunological Guidance of Genetic Analyses Including Exome Sequencing in Patients Evaluated for Hemophagocytic Lymphohistiocytosis. J Clin Immunol. 2017 Nov;37(8):770-80.

8. Pagán AJ, Ramakrishnan L. The Formation and Function of Granulomas. Annu Rev Immunol. 2018 Apr 26;36(1):639-65.

9. Makino K, Takeichi O, Hatori K, Imai K, Ochiai K, Ogiso B. Epstein-Barr Virus Infection in Chronically Inflamed Periapical Granulomas. Pagano JS, editor. PLOS ONE. 2015 Apr 17;10(4):e0121548.

10. Bodemer C, Sauvage V, Mahlaoui N, Cheval J, Couderc T, Leclerc-Mercier S, et al. Live rubella virus vaccine long-term persistence as an antigenic trigger of cutaneous granulomas in patients with primary immunodeficiency. Clin Microbiol Infect. 2014 Oct;20(10):0656-63.

11. Neven B, Pérot P, Bruneau J, Pasquet M, Ramirez M, Diana J-S, et al. Cutaneous and Visceral Chronic Granulomatous Disease Triggered by a Rubella Virus Vaccine Strain in Children With Primary Immunodeficiencies: Table 1. Clin Infect Dis. 2017 Jan 1;64(1):83-6.

12. Perelygina L, Plotkin S, Russo P, Hautala T, Bonilla F, Ochs HD, et al. Rubella persistence in epidermal keratinocytes and granuloma $\mathrm{M} 2$ macrophages in patients with primary immunodeficiencies. J Allergy Clin Immunol. 2016 Nov;138(5):1436-1439.e11. 
13. Perelygina L, Icenogle J, Sullivan KE. Rubella virus-associated chronic inflammation in primary immunodeficiency diseases. Curr Opin Allergy Clin Immunol [Internet]. 2020 Oct 9 [cited 2020 Oct 14]; Publish Ahead of Print. Available from: https://journals.Iww.com/10.1097/ACI.0000000000000694

14. Perelygina L, Chen $M-H$, Suppiah S, Adebayo A, Abernathy E, Dorsey $M$, et al. Infectious vaccine-derived rubella viruses emerge, persist, and evolve in cutaneous granulomas of children with primary immunodeficiencies. PLoS Pathog. 2019 Oct;15(10):e1008080.

15. Robert Koch-Institut. Epidemiologisches Bulletin 18/2019 - Impfquoten bei der Schuleingangsuntersuchung in Deutschland 2017. 2019 May 2 [cited 2020 May 5]; Available from: https://www.rki.de/DE/Content/Infekt/EpidBull/Archiv/2019/Ausgaben/18_19.pdf? blob=publicationFile

16. Bryceson YT, Pende D, Maul-Pavicic A, Gilmour KC, Ufheil H, Vraetz T, et al. A prospective evaluation of degranulation assays in the rapid diagnosis of familial hemophagocytic syndromes. Blood. 2012;119(12):2754-2763.

17. Vargas $P$, Terriac E, Lennon-Duménil A-M, Piel M. Study of Cell Migration in Microfabricated Channels. J Vis Exp. 2014 Feb 21;(84):51099.

18. Sáez PJ, Barbier L, Attia R, Thiam H-R, Piel M, Vargas P. Leukocyte Migration and Deformation in Collagen Gels and Microfabricated Constrictions. In: Gautreau A, editor. Cell Migration [Internet]. New York, NY: Springer New York; 2018 [cited 2019 May 28]. p. 361-73. Available from: http://link.springer.com/10.1007/978-1-4939-7701-7_26

19. Colvin RA, Means TK, Diefenbach TJ, Moita LF, Friday RP, Sever S, et al. Synaptotagminmediated vesicle fusion regulates cell migration. Nat Immunol. 2010 Jun;11(6):495502.

20. Singh RK, Mizuno K, Wasmeier C, Wavre-Shapton ST, Recchi C, Catz SD, et al. Distinct and opposing roles for Rab27a/Mlph/MyoVa and Rab27b/Munc13-4 in mast cell secretion. FEBS J. 2012 Dec;n/a-n/a.

21. Franciszkiewicz K, Boutet M, Gauthier L, Vergnon I, Peeters K, Duc O, et al. Synaptic Release of CCL5 Storage Vesicles Triggers CXCR4 Surface Expression Promoting CTL Migration in Response to CXCL12. J Immunol. 2014 Nov 15;193(10):4952-61.

22. Capece T, Walling BL, Lim K, Kim K-D, Bae S, Chung H-L, et al. A novel intracellular pool of LFA-1 is critical for asymmetric CD8+ T cell activation and differentiation. J Cell Biol. 2017 Nov 6;216(11):3817-29.

23. Griscelli C, Durandy A, Guy-Grand D, Daguillard F, Herzog C, Prunieras M. A syndrome associating partial albinism and immunodeficiency. Am J Med. 1978 Oct;65(4):691-702.

24. Klein C, Philippe N, Le Deist F, Fraitag S, Prost C, Durandy A, et al. Partial albinism with immunodeficiency (Griscelli syndrome). J Pediatr. 1994 Dec;125(6 Pt 1):886-95. 
605

606

607

608

609

610

611

612

613

614

615

616

617

618

619

620

621

622

623

624

625

626

627

628

629

630

631

632

633

634

635

636

637

638

639

640

641

642

25. Kuo PT, Zeng Z, Salim N, Mattarollo S, Wells JW, Leggatt GR. The Role of CXCR3 and Its Chemokine Ligands in Skin Disease and Cancer. Front Med. 2018 Sep 25;5:271.

26. Metzemaekers $M$, Vanheule V, Janssens R, Struyf S, Proost P. Overview of the Mechanisms that May Contribute to the Non-Redundant Activities of InterferonInducible CXC Chemokine Receptor 3 Ligands. Front Immunol. 2018 Jan 15;8:1970.

27. Hickman HD, Reynoso GV, Ngudiankama BF, Cush SS, Gibbs J, Bennink JR, et al. CXCR3 Chemokine Receptor Enables Local CD8+ T Cell Migration for the Destruction of VirusInfected Cells. Immunity. 2015 Mar;42(3):524-37.

28. Bender NR, Cardwell LA, Siegel D, Sokumbi O. Rubella Vaccine Persistence Within Cutaneous Granulomas in Common Variable Immunodeficiency Disorder: Am J Dermatopathol. 2020 Jun;42(6):455-7.

29. Buchbinder D, Hauck F, Albert MH, Rack A, Bakhtiar S, Shcherbina A, et al. Rubella Virus-Associated Cutaneous Granulomatous Disease: a Unique Complication in Immune-Deficient Patients, Not Limited to DNA Repair Disorders. J Clin Immunol [Internet]. 2019 Jan 3 [cited 2019 Jan 8]; Available from:

http://link.springer.com/10.1007/s10875-018-0581-0

30. Deripapa E, Balashov D, Rodina Y, Laberko A, Myakova N, Davydova NV, et al. Prospective Study of a Cohort of Russian Nijmegen Breakage Syndrome Patients Demonstrating Predictive Value of Low Kappa-Deleting Recombination Excision Circle (KREC) Numbers and Beneficial Effect of Hematopoietic Stem Cell Transplantation (HSCT). Front Immunol [Internet]. 2017 Jul 24 [cited 2019 Jan 16];8. Available from: http://journal.frontiersin.org/article/10.3389/fimmu.2017.00807/full

31. Dhossche J, Johnson L, White K, Funk T, Leitenberger S, Perelygina L, et al. Cutaneous Granulomatous Disease With Presence of Rubella Virus in Lesions. JAMA Dermatol. 2019 Jul 1;155(7):859-61.

32. Leclerc-Mercier S, Moshous D, Neven B, Mahlaoui N, Martin L, Pellier I, et al. Cutaneous granulomas with primary immunodeficiency in children: a report of 17 new patients and a review of the literature. J Eur Acad Dermatol Venereol. 2019 Apr 15;jdv.15568.

33. Tsuge I, Matsuoka H, Torii S, Okada J, Mizuno T, Matsuoka M, et al. Preservation of natural killer and interleukin-2 activated killer cell activity in ataxia-telangiectasia with $T$ cell deficiency. J Clin Lab Immunol. 1987 May;23(1):7-13.

34. Singh RK, Liao W, Tracey-White D, Recchi C, Tolmachova T, Rankin SM, et al. Rab27amediated protease release regulates neutrophil recruitment by allowing uropod detachment. J Cell Sci. 2012 Apr 1;125(7):1652-6.

35. Jessen B, Maul-Pavicic A, Ufheil H, Vraetz T, Enders A, Lehmberg K, et al. Subtle differences in CTL cytotoxicity determine susceptibility to hemophagocytic lymphohistiocytosis in mice and humans with Chediak-Higashi syndrome. Blood. 2011 Oct 27;118(17):4620-9. 
36. Sepulveda FE, Debeurme F, Ménasché G, Kurowska M, Côte M, Pachlopnik Schmid J, et al. Distinct severity of $\mathrm{HLH}$ in both human and murine mutants with complete loss of cytotoxic effector PRF1, RAB27A, and STX11. Blood. 2013 Jan 24;121(4):595-603.

37. Farnaes L, Coufal NG, Spector SA. Vaccine Strain Varicella Infection in an Infant With Previously Undiagnosed Perinatal Human Immunodeficiency Type-1 Infection: Pediatr Infect Dis J. 2019 Apr;38(4):413-5.

38. Iroh Tam P-Y, Hanisch BR, Klammer K, DeVries AS. Measles Vaccine Strain From the Skin Rash of a DiGeorge Patient Receiving Tumor Necrosis Factor Inhibitor: Pediatr Infect Dis J. 2014 Jan;33(1):117.

39. Kägi D, Seiler P, Pavlovic J, Ledermann B, Bürki K, Zinkernagel RM, et al. The roles of perforin-and Fas-dependent cytotoxicity in protection against cytopathic and noncytopathic viruses. Eur J Immunol. 1995;25(12):3256-3262.

40. Dix RD, Podack ER, Cousins SW. Loss of the Perforin Cytotoxic Pathway Predisposes Mice to Experimental Cytomegalovirus Retinitis. J Virol. 2003 Mar 15;77(6):3402-8.

41. Gather R, Aichele P, Goos N, Rohr J, Pircher H, Kögl T, et al. Trigger-dependent differences determine therapeutic outcome in murine primary hemophagocytic lymphohistiocytosis. Eur J Immunol [Internet]. 2020 Jun 2 [cited 2020 Oct 15]; Available from: https://onlinelibrary.wiley.com/doi/abs/10.1002/eji.201948123

42. Rossi CP, McAllister A, Tanguy $M$, Kägi $D$, Brahic $M$. Theiler's virus infection of perforindeficient mice. J Virol. 1998;72(5):4515-4519.

43. Müllbacher A, Hla RT, Museteanu C, Simon MM. Perforin is essential for control of ectromelia virus but not related poxviruses in mice. J Virol. 1999;73(2):1665-1667.

44. Allen DJ, Brooks JW, Cardin RD, Doherty PC, Sarawar SR, Nash AA, et al. Immunological control of murine gammaherpesvirus infection is independent of perforin. J Gen Virol. 1997 Aug 1;78(8):2025-30.

45. Frey S, Krempl CD, Schmitt-Gräff A, Ehl S. Role of T Cells in Virus Control and Disease after Infection with Pneumonia Virus of Mice. J Virol. 2008 Dec 1;82(23):11619-27.

46. Lin MT, Stohlman SA, Hinton DR. Mouse hepatitis virus is cleared from the central nervous systems of mice lacking perforin-mediated cytolysis. J Virol. 1997;71(1):38391.

47. Aung S, Rutigliano JA, Graham BS. Alternative Mechanisms of Respiratory Syncytial Virus Clearance in Perforin Knockout Mice Lead to Enhanced Disease. J Virol. 2001 Oct $15 ; 75(20): 9918-24$.

48. Franco MA, Tin C, Rott LS, Vancott JL, Mcghee JR, Greenberg HB. Evidence for CD8+ TCell Immunity to Murine Rotavirus in the Absence of Perforin, Fas, and Gamma Interferon. J VIROL. 1997;71:8. 
679

680

681

682

683

684

685

686

687

688

689

690

691

692

693

694

695

696

697

698

699

700

701

702

703

704

705

49. Kägi D, Ledermann B, Bürki K, Zinkernagel RM, Hengartner H. Molecular mechanisms of lymphocyte-mediated cytotoxicity and their role in immunological protection and pathogenesis in vivo. Annu Rev Immunol. 1996;14(1):207-232.

50. Kägi D, Ledermann B, Burki K, Zinkernagel RFM, Hengartner H. Lymphocyte-mediated Cytotoxicity in vitro and in vivo: Mechanisms and Significance. Immunol Rev. 1995 Aug;146(1):95-115.

51. Tesi B, Rascon J, Chiang SCC, Burnyte B, Löfstedt A, Fasth A, et al. A RAB27A 5' untranslated region structural variant associated with late-onset hemophagocytic lymphohistiocytosis and normal pigmentation. J Allergy Clin Immunol [Internet]. 2018 Mar [cited 2018 Apr 13]; Available from: http://linkinghub.elsevier.com/retrieve/pii/S0091674918303233

52. Eyer D, Petiau P, Finck S, Heid E, Grosshans E, Lutz P. [Granulomatous skin lesions in Griscelli disease]. Ann Dermatol Venereol. 1998 Oct;125(10):727-8.

53. Navarrete $\mathrm{CL}$, Araníbar L, Mardones F, Avila R, Velozo L. Cutaneous granulomas in Griscelli type 2 syndrome. Int J Dermatol. 2016 Jul;55(7):804-5.

54. Gotesman R, Ramien M, Armour CM, Pham-Huy A, Kirshen C. Cutaneous granulomas as the presenting manifestation of Griscelli syndrome type 2. Pediatr Dermatol [Internet]. 2020 Sep 23 [cited 2020 Oct 5]; Available from: https://onlinelibrary.wiley.com/doi/10.1111/pde.14370

55. Murphy MJ. Necrotizing palisaded granulomatous dermatitis as a manifestation of familial hemophagocytic lymphohistiocytosis. J Cutan Pathol. 2009 Nov 9;37(8):907-10.

56. Akyol S, Ozcan A, Sekine T, Chiang SCC, Yilmaz E, Karakurkcu M, et al. Different Clinical Presentation of 3 Children With Familial Hemophagocytic Lymphohistiocytosis With 2 Novel Mutations. J Pediatr Hematol Oncol. 2020 Oct;42(7):e627-9.

57. Vargas $P$, Chabaud $M$, Thiam H-R, Lankar D, Piel M, Lennon-Dumenil A-M. Study of dendritic cell migration using micro-fabrication. J Immunol Methods. 2016 May;432:30-4. 


\section{Tables}

707 Table 1: Clinical Characteristics of Patients with Cytotoxicity Defects and Clinical Granulomas

\begin{tabular}{|c|c|c|c|c|c|c|c|c|c|c|c|}
\hline Patient & Diagnosis & $\begin{array}{c}\text { Age at } \\
\text { Vaccination } \\
\text { [Months] }\end{array}$ & $\begin{array}{c}\text { Age at } \\
\text { granuloma } \\
\text { onset }\end{array}$ & $\begin{array}{l}\text { Age at HLH } \\
\text { onset }\end{array}$ & Description of skin alteration* & $\begin{array}{l}\text { Extracutaneous } \\
\text { granulomas }\end{array}$ & $\begin{array}{l}\text { Consistent } \\
\text { Photodocu- } \\
\text { mentation }\end{array}$ & $\begin{array}{l}\text { Granulomas } \\
\text { confirmed by } \\
\text { histology }\end{array}$ & $\begin{array}{c}\text { Rubella } \\
\text { identified }\end{array}$ & $\begin{array}{l}\text { Criteria } \\
\text { fulfilled }\end{array}$ & $\begin{array}{c}\text { Identified } \\
\text { via }\end{array}$ \\
\hline $\mathrm{P} 1$ & GS2 & $15+25$ & $22 \mathrm{M}$ & no $\mathrm{HLH}$ & $\begin{array}{l}\text { papulopustular, granulomatous exanthema } \\
\text { on limbs and face }\end{array}$ & $N / R$ & yes & yes & $\begin{array}{l}\mathrm{IHC}+\mathrm{PCR} \\
\text { (skin) }\end{array}$ & $4 / 4$ & $\begin{array}{c}\text { Index } \\
\text { Patient, } \mathrm{R}\end{array}$ \\
\hline P2 & GS2 & $15+72$ & $17 \mathrm{M}$ & no HLH & $\begin{array}{l}\text { skin rash, macules evolving into papules on } \\
\text { face and limbs }\end{array}$ & $\begin{array}{l}\text { non-specific granulomatous } \\
\text { microfoci in CNS }\end{array}$ & yes & yes & IHC (skin) & $4 / 4$ & $\mathrm{P} 4$ in (51) \\
\hline P3 & GS2 & $\mathrm{N} / \mathrm{A}$ & $36 \mathrm{M}$ & $4.5 \mathrm{Y}$ & $\begin{array}{l}\text { papular, inflammatory lesions on lower } \\
\text { limbs, buttocks and cheeks, some ulcerating }\end{array}$ & $N / R$ & yes & yes & IHC (skin) & $4 / 4$ & $(52)$ \\
\hline $\mathrm{P} 4$ & GS2 & $12^{\S}$ & $12-21 \mathrm{M}$ & $\begin{array}{l}>2 \mathrm{M} \text { after } \\
\text { granuloma onset }\end{array}$ & $\begin{array}{l}\text { multiple red, crusted papules on cheeks and } \\
\text { thighs }\end{array}$ & $N / R$ & yes & yes & $\mathrm{N} / \mathrm{A}$ & $3 / 4$ & (53) \\
\hline P5 & GS2 & 18 & $24 \mathrm{M}$ & $14.5 \mathrm{Y}$ & skin granulomas on arms and legs & $N / R$ & $\mathrm{~N} / \mathrm{A}$ & yes & N/A & $2 / 4$ & P2 in (51) \\
\hline P6 & GS2 & $16+18$ & $22 \mathrm{M}$ & no HLH & pustules on limbs & $N / R$ & yes & yes & $\begin{array}{c}\mathrm{IHC}+\mathrm{PCR} \\
\text { (skin) }\end{array}$ & $4 / 4$ & $\mathrm{R}$ \\
\hline P7 & GS2 & 12 & $16 \mathrm{M}$ & $17.3 \mathrm{Y}$ & pustules on limbs, face, buttocks & $N / R$ & yes & N/A & $\mathrm{N} / \mathrm{A}$ & $2 / 4$ & $\mathrm{R}$ \\
\hline P8 & GS2 & $17+78$ & $92 \mathrm{M}$ & $\begin{array}{c}\text { incomplete HLH } \\
(7.8 \mathrm{Y})\end{array}$ & skin rash / extensive skin lesions & lung & yes & yes & $\begin{array}{c}\mathrm{IHC} \\
\text { (skin + lung) }\end{array}$ & $4 / 4$ & Lithuania \\
\hline P9 & GS2 & 12 & $13 \mathrm{M}$ & $8.7 \mathrm{Y}$ & $\begin{array}{l}\text { erythematous papules, granulomatous } \\
\text { inflammation }\end{array}$ & $N / R$ & $\mathrm{~N} / \mathrm{A}$ & yes & IHC (skin) & $3 / 4$ & $\mathrm{R}$ \\
\hline P10 & GS2 & 12 & $13 \mathrm{M}$ & no HLH & papules on trunk and limbs & $N / R$ & yes & N/A & $\mathrm{N} / \mathrm{A}$ & $2 / 4$ & $\mathrm{R}$ \\
\hline P11 & GS2 & 12 & $14 \mathrm{M}$ & $3.1 Y$ & red papules on face, limbs and buttocks & $N / R$ & N/A & yes & N/A & $2 / 4$ & $\mathrm{R}$ \\
\hline P12 & GS2 & N/A & $\begin{array}{c}\text { since } \\
\text { childhood }\end{array}$ & no HLH & red papules & liver, muscle & yes & yes & $\begin{array}{c}\text { IHC } \\
\text { (skin + liver) } \\
\end{array}$ & $4 / 4$ & $\mathrm{R}$ \\
\hline $\mathrm{P} 13$ & GS2 & 16 & $16.5 \mathrm{M}$ & $5 Y$ & $\begin{array}{l}\text { non-pruritic, erythematous-violaceous } \\
\text { papules on cheeks, limbs and buttocks }\end{array}$ & N/A & yes & yes & N/A & $3 / 4$ & (54) \\
\hline P14 & FHL2 & 52 & $72 \mathrm{M}$ & 8 Y (CNS only) & no skin granulomas & lung & N/A & yes & IHC (lung) & $2 / 4$ & Australia \\
\hline $\mathrm{P} 15$ & FHL2 & $16-40$ & $28-40 M$ & $8.5 \mathrm{Y}$ & $\begin{array}{l}\text { erythematous papular and hyperkeratotic } \\
\text { skin lesions on arm and face }\end{array}$ & $N / R$ & yes & yes & $\begin{array}{c}\mathrm{IHC}+\mathrm{PCR} \\
\text { (skin) }\end{array}$ & $4 / 4$ & France \\
\hline $\mathrm{P} 16$ & FHL3 & N/A & $18 \mathrm{M}$ & $\begin{array}{l}\text { after granuloma } \\
\text { onset }\end{array}$ & $\begin{array}{l}\text { necrotizing palisaded granulomatous } \\
\text { dermatitis, small papules on arms and legs }\end{array}$ & $N / R$ & N/A & yes & $\mathrm{N} / \mathrm{A}$ & $2 / 4$ & $(55)$ \\
\hline $\mathrm{P} 17$ & FHL3 & $12+22$ & $24 \mathrm{M}$ & $\begin{array}{c}\text { incomplete HLH } \\
(10 \mathrm{Y})\end{array}$ & $\begin{array}{l}\text { small granuloma on right upper thigh, } \\
\text { increasing in size over time to } 4 \times 3 \mathrm{~cm}\end{array}$ & $N / R$ & yes & yes & IHC (skin) & $4 / 4$ & $\mathrm{R}$ \\
\hline $\mathrm{P} 18$ & FHL3 & 12 & $16 \mathrm{M}$ & $3.6 \mathrm{Y}$ & $\begin{array}{l}\text { individual purplish papules with some } \\
\text { overlying scale on the face, arms and legs }\end{array}$ & $N / R$ & yes & yes & IHC (skin) & $4 / 4$ & Australia \\
\hline P19 & FHL3 & 12 & $48 \mathrm{M}$ & $6 \mathrm{Y}$ & $\begin{array}{l}\text { irregular single maculopapular lesion on left } \\
\text { calf }\end{array}$ & lung & yes & yes & $\begin{array}{c}\mathrm{IHC} \\
\text { (skin + lung) }\end{array}$ & $4 / 4$ & Australia \\
\hline P20 & FHL3 & N/A & $18 \mathrm{M}$ & $21 \mathrm{M}$ & dense rash on arms, legs and face & N/A & yes & N/A & N/A & $2 / 4$ & P1 in (56) \\
\hline P21 & FHL5 & $\mathrm{N} / \mathrm{A}$ & $43 \mathrm{M}$ & $45 \mathrm{M}$ & $\begin{array}{l}\text { erythematous papules on lower limbs and } \\
\text { occasionally on belly }\end{array}$ & $N / R$ & $\mathrm{~N} / \mathrm{A}$ & $\mathrm{N} / \mathrm{A}$ & $\mathrm{N} / \mathrm{A}$ & $1 / 4$ & $\mathrm{R}$ \\
\hline
\end{tabular}


711 Abbreviations: $N / R=$ not reported, $N / A=$ not available, $C N S=$ central nervous system, GS2 $=$ Griscelli syndrome type 2, FHL = familial hemophagocytic lymphohistiocytosis, IHC = 


\section{Figure legends:}

716

717

Figure 1: Clinical pictures of cutaneous skin lesions in patients with cytotoxicity defects.

Figure 2: Histopathological findings in patients with rubella-associated granulomas. (A) Skin biopsy of P2 stained with HE, showing multiple dermal epithelioid granulomas and epidermal hyperkeratosis. Double staining with anti-CD68 (red) and anti-RV-C (brown) revealed double positive cells, including giant cells, in the center of the granulomas. Anti-CD8 staining showed infiltrating CD8+ T cells in the periphery of the granulomas. Scale bar $=200 \mu \mathrm{m}$ (left), $20 \mu \mathrm{m}$ (right). (B) Double staining of the lung biopsy of P14. Scale bar $=50 \mu \mathrm{m}$ (upper), $20 \mu \mathrm{m}$ (lower). (C) Distribution of RV capsid positive cells in skin samples. Positive cells were located within granulomas or loosely formed granuloma-like histiocytic aggregates. Scale bar $=20 \mu \mathrm{m}$.

Figure 3: Clinical course of granulomas in patients with cytotoxicity defects. Time periods during which granulomas were reported are depicted as grey boxes, whereas white boxes (labelled with "?") indicate that detailed information on granuloma persistence was not available. Age at vaccination is indicated by triangles, age at granuloma onset (if known) is indicated by an arrow, time point of HSCT by a cross.

Figure 4: Risk of granuloma development for patients with cytotoxicity defects. (A) Recruitment scheme for patients in the "AT RISK" cohort. (B) Percentage of cases with skin alterations consistent with rubella granulomas, categorized by underlying genetic disorder. (C) Activity of NK cells from GS2 patients with (+ gran.) and without (- gran.) granulomas measured by degranulation assay of resting NK cells. $\triangle \mathrm{CD} 107 \mathrm{a}$ indicates the difference in the fraction of NK cells expressing CD107a under 
739

740

741

742

743

744

745

746

747

748

749

750

751

752

753

754

755

756

757

758

759

760

761

762

763

unstimulated and stimulated conditions. Grey shaded area represents normal values (10 $10^{\text {th }}$ percentile of 94 healthy controls). (D) Distribution of granuloma cases among patients with different cytotoxicity defects. Left: Patients included in "AT RISK" cohort, right: all patients with clinical granulomas (skin and visceral).

Figure 5: $T$ cell chemotaxis and migration are not affected by mutations in RAB27A or UNC13D. (A) CXCR3 surface expression on CD8+ T cell lines from healthy donors (HD) and patients with mutations in RAB27A, UNC13D or ATM after stimulation with $100 \mathrm{nM}$ CXCL11. Results from 2 individual experiments are summarized on the left (mean $+/-\mathrm{SD}$ ), representative histograms are shown on the right. (B) Transwell migration of CD8+ T-cell lines towards CXCL10 or CXCL12. Each experiment was performed once. (C) Scheme of the micro-channel device used to assess cell speed. Cells are loaded in the round loading chamber and from there spontaneously migrate into the micro-channels (upper section). Lower section depicts CD8+ T-cell lines (labelled with Hoechst33342) moving within $4 \mu \mathrm{m}$ wide microchannels. Scale bar $=100 \mu \mathrm{m}$. Scheme adapted from Vargas et al. 2016 (57). Mean speeds of 3 individual experiments for $3 \mathrm{HD}$ and patients with mutations in PRF1 (n=1), STXBP2 $(n=1), \operatorname{RAB} 27 A(n=2), \operatorname{UNC13D}(n=3)$ are shown as individual values, bars represent mean speed of pooled results +/- SD. (D) Schematic drawing of the custommade PDMS chamber loaded with a mixture of cells and collagen (grey lines), adapted from Sáez et al., 2018 (18). Bright field image of CD8+ T-cell lines moving within the $3 \mathrm{D}$ collagen matrix $(3 \mathrm{mg} / \mathrm{ml}$ rat tail collagen type I). Cell tracks after $60 \mathrm{~min}$ of cell migration are overlaid as colored lines. Scale bar $=200 \mu \mathrm{m} .120$ cells were tracked per experiment, bars represent mean speed of pooled results +/- SD. (C+D) Open circles represent results obtained for T-cell lines derived from patients with skin granulomas. Statistical analysis: Ordinary one-way ANOVA with Dunnett's multiple comparisons test. 
Fig. 1

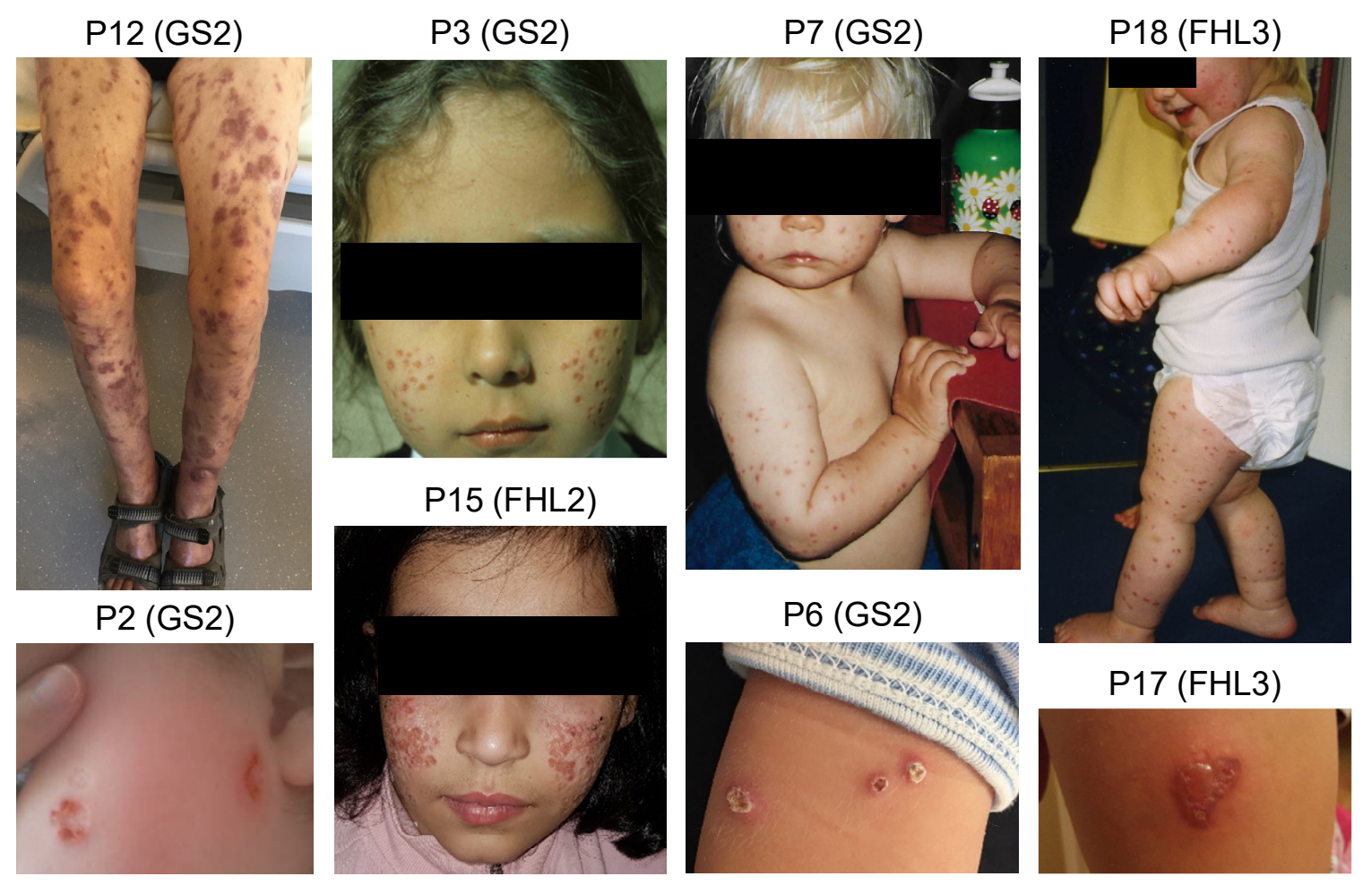


Fig. 2

A
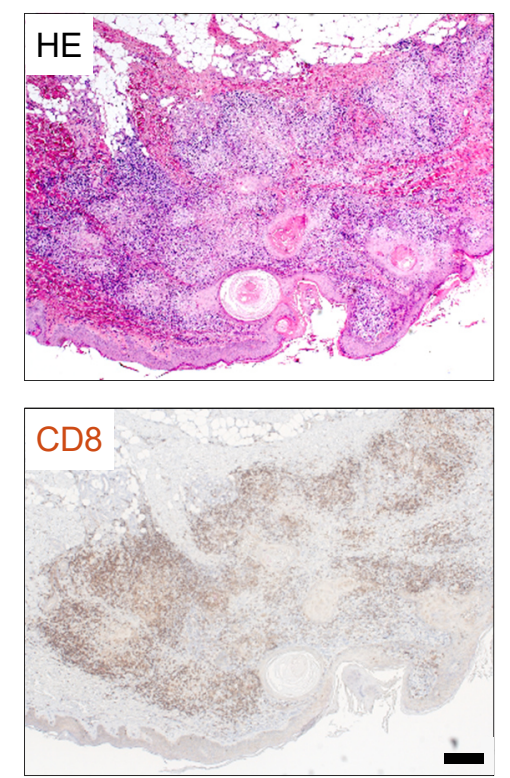

C

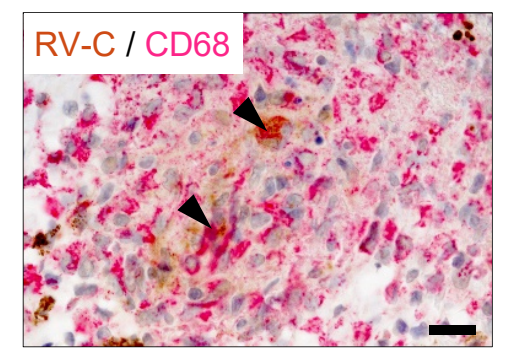

P2 (GS2)

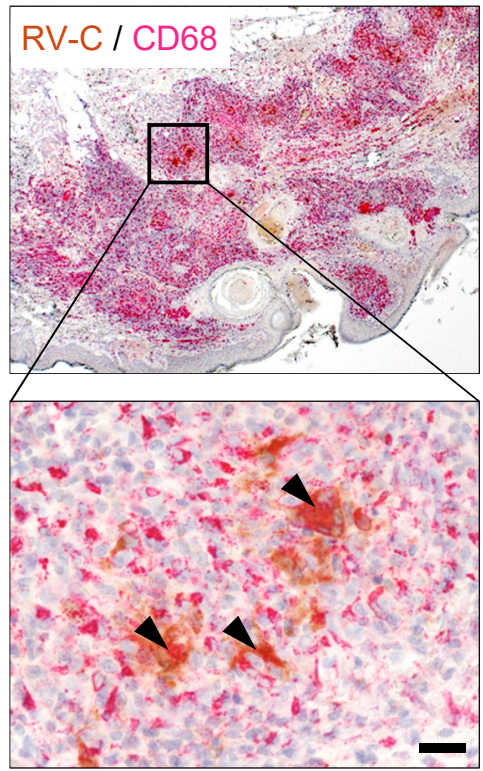

P19 (FHL3)

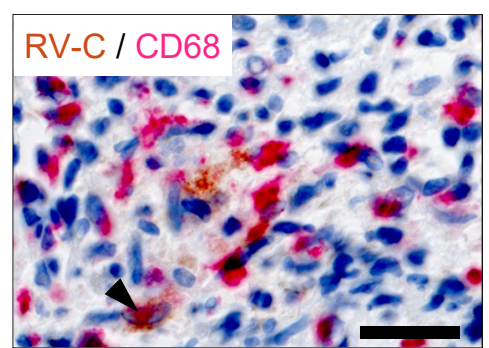

B P14 (FHL2)

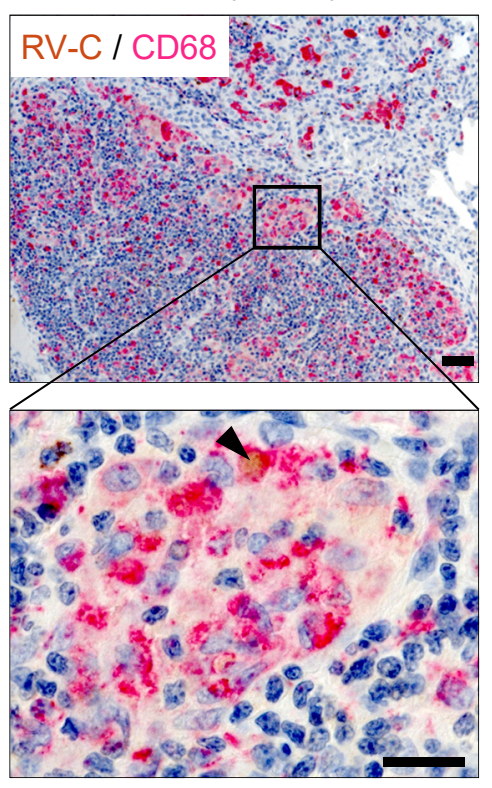

P15 (FHL2)

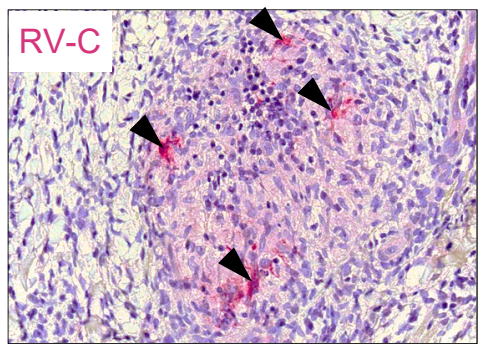


Fig. 3

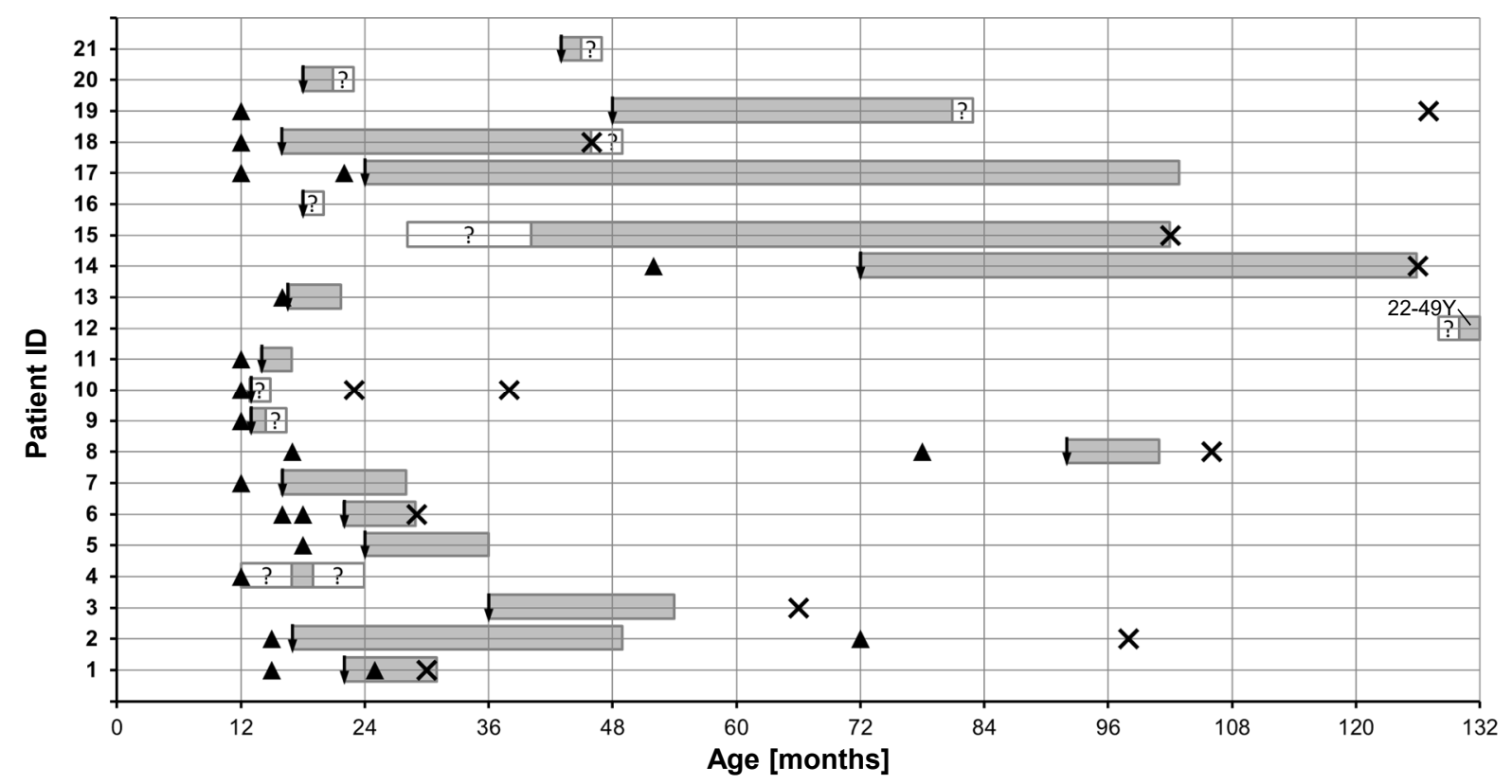

$\Delta$ MMR vaccination $\quad \times$ HSCT $\downarrow$ granuloma onset

granuloma present ? no information on first manifestation or disappearance of granulomas available 
A

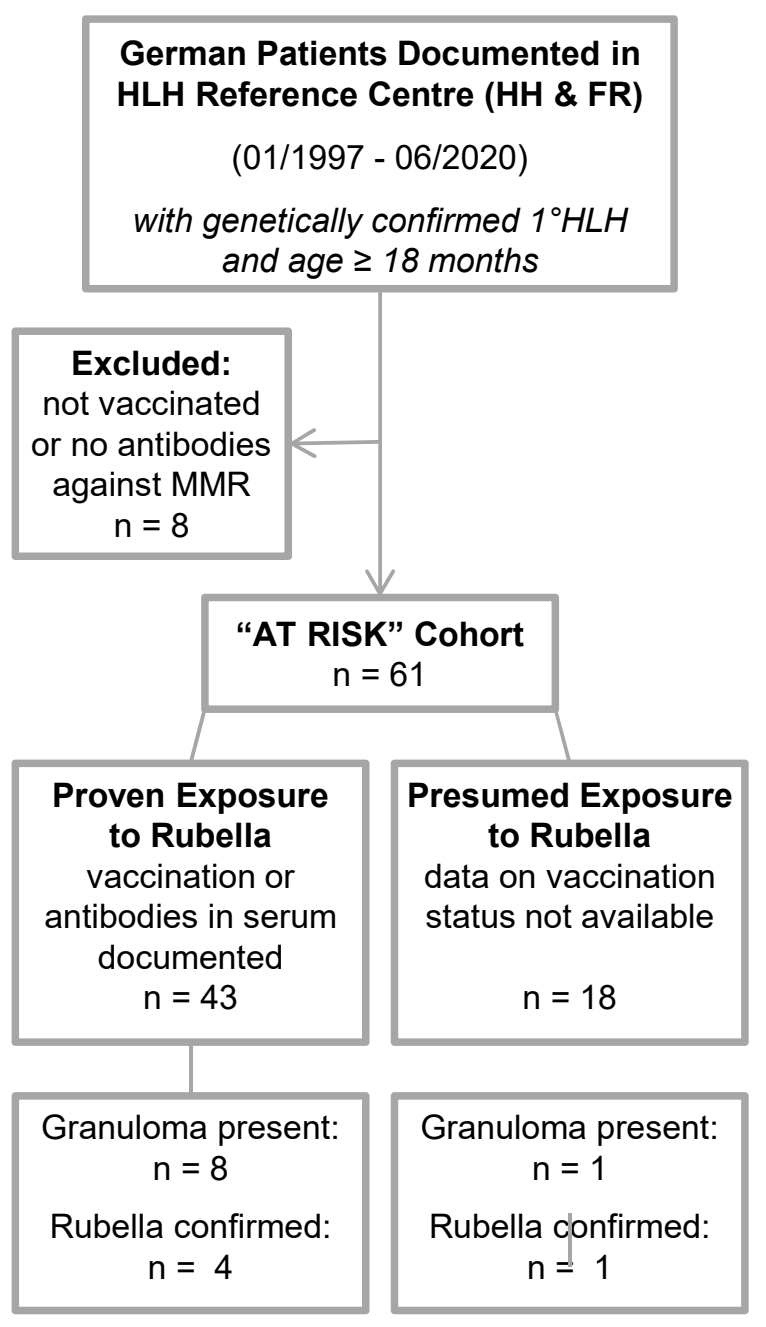

B

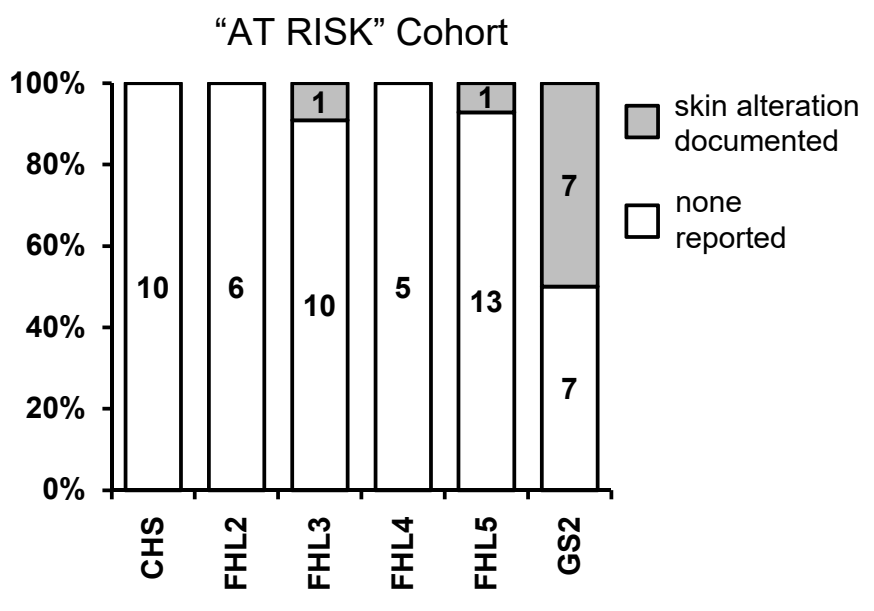

C

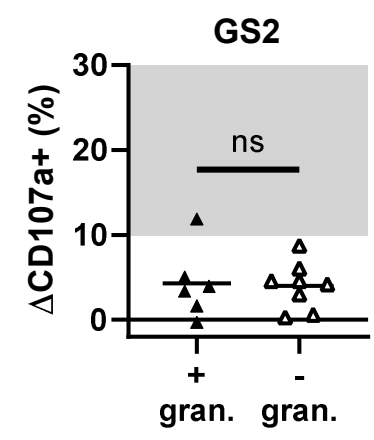

D Patients with Granulomas

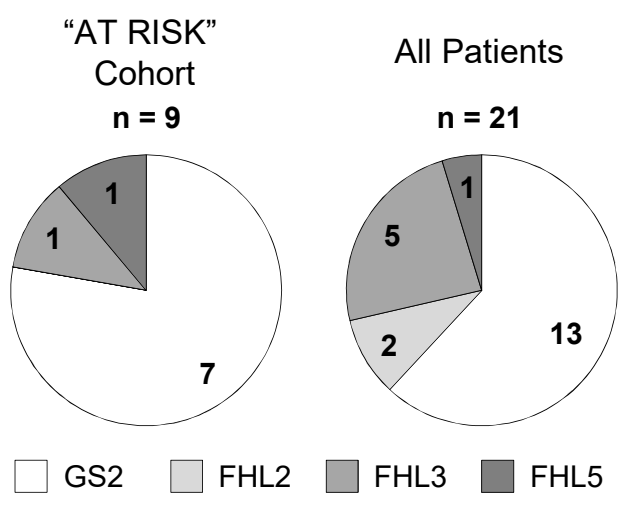


Fig. 5

A

Chemokine receptor expression and downregulation

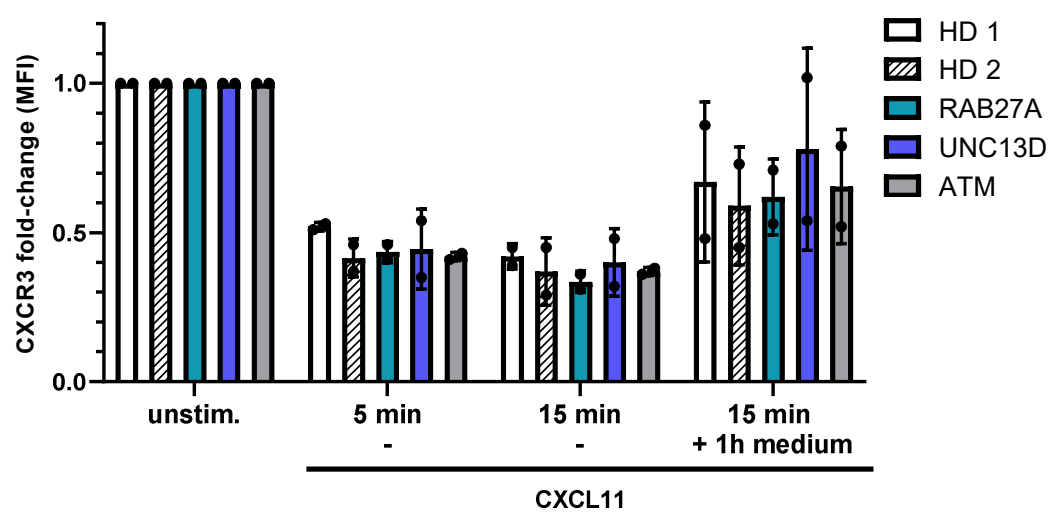

B

Chemotaxis of CD8+ T cells

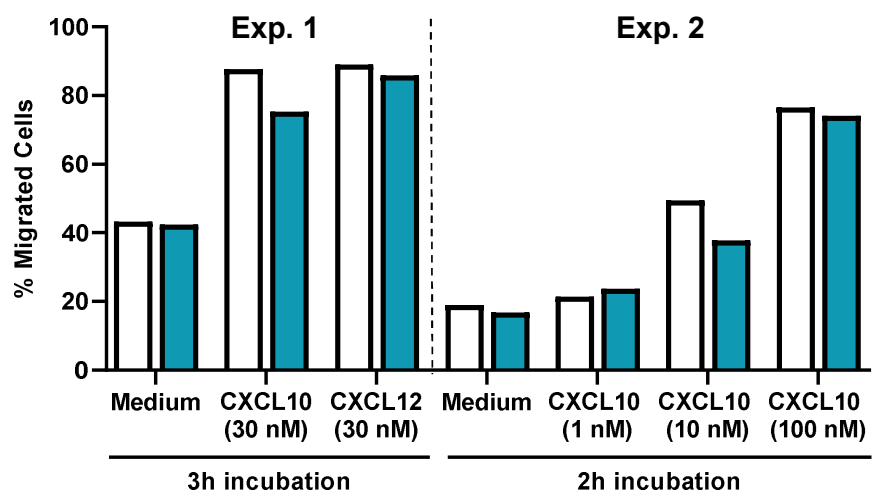

\section{$\square$ HD}

$\square$ RAB27A

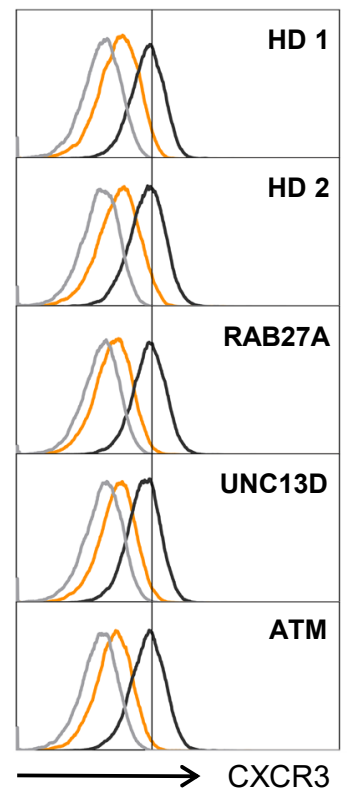

Isotype

$\square$ unstimulated

$\square 15$ min CXCL11 (100 nM)

C

Migration in micro-channels
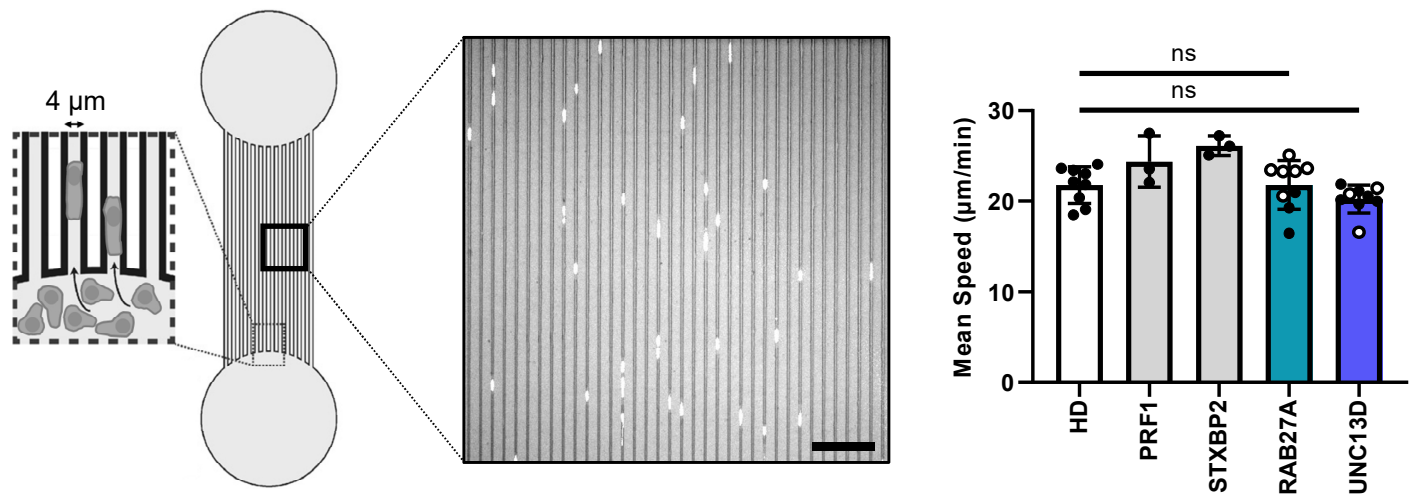

D

Migration in collagen type I
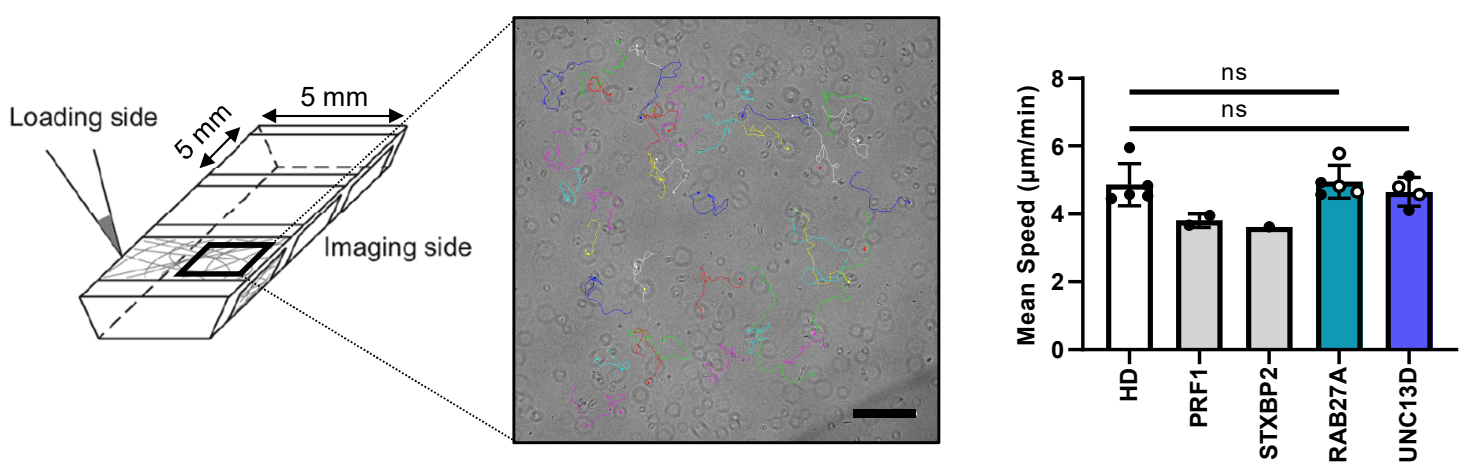